\title{
Ultrasensitive detection of human liver hepatocellular carcinoma (HepG2) cells using a label-free aptasensor
}

\author{
Leila Kashefi-Kheyrabadi, Masoud A. Mehrgardi, Emilia Wiechec, \\ Anthony P.F. Turner and Ashutosh Tiwari
}

\section{Linköping University Post Print}

\section{Tweet}

N.B.: When citing this work, cite the original article.

Original Publication:

Leila Kashefi-Kheyrabadi, Masoud A. Mehrgardi, Emilia Wiechec, Anthony P.F. Turner and Ashutosh Tiwari, Ultrasensitive detection of human liver hepatocellular carcinoma (HepG2) cells using a label-free aptasensor, 2014, Analytical Chemistry, (86), 10, 4956-4960.

http://dx.doi.org/10.1021/ac500375p

Copyright: American Chemical Society http://pubs.acs.org/

Postprint available at: Linköping University Electronic Press http://urn.kb.se/resolve?urn=urn:nbn:se:liu:diva-107976 